\title{
Making intrinsic values work; integrating intrinsic values of the more-than-human world through the Life Framework of Values
}

\author{
Seb O'Connor ${ }^{1,2}\left(\mathbb{D} \cdot\right.$ Jasper O. Kenter ${ }^{1,3}$
}

Received: 2 August 2018 / Accepted: 27 June 2019 / Published online: 23 July 2019

(c) The Author(s) 2019

\begin{abstract}
This paper addresses central limitations of ecosystem services and nature's contributions to people (NCP) by developing a novel approach to consideration of intrinsic values of nature. Intrinsic values are seen as bundled with values of ecosystem services and NCP within the Life Framework, an innovative, comprehensive and easy to communicate framework of values. Building on work by John O'Neill, values are conceived of as related to living with, from, in and as the world. These frames are related to but distinct from more formal ethical justifications of intrinsic, instrumental and relational values, which straddle the four Life Frames. Focusing on intrinsic values, we conceive these as ends without reference to humans as valuers, but which nonetheless can be articulated by people. We draw on more-than-human participatory research and post-normal science to promote the articulation and deliberation of perspectives and interests of the more-than-human world by an extended peer community. This clearly differentiates our approach from both rights-based intrinsic value and utilitarian existence value approaches, although it is inclusive of them. The approach is demonstrated by an elaborate integrated marine ecosystem valuation, where we investigate associations between intrinsic and relational values and the four Life frames. The Life Framework, operationalised through the post-normal, more-than-human participatory approach, operationalises articulated intrinsic values in a way that puts them on an equal footing with values of ecosystem services and NCP, providing an opportunity to bridge and reconcile these different types of value through deliberation. This enhances the recognition and procedural justice of valuation, while at the same time retaining the practical advantages that the ecosystem services framework brings.
\end{abstract}

Keywords Articulated intrinsic values $\cdot$ Relational values $\cdot$ Shared values $\cdot$ Social values $\cdot$ Deliberative democracy $\cdot$ Morethan-human participatory research $\cdot$ Environmental ethics

\section{Introduction}

The ecosystem services (ES) framework focuses on the benefits people derive from nature and the ecological processes that underpin these, providing a powerful tool to argue for their protection (TEEB 2010; UK NEA 2011,

Handled by Dave Kendal, University of Tasmania, Australia.

Jasper O. Kenter

fhso@leeds.ac.uk; jasper.kenter@york.ac.uk

Scottish Association for Marine Science (SAMS), Oban, UK

2 School of Fine of Art, History of Art and Cultural Studies, University of Leeds, Leeds, UK

3 Department of Environment and Geography, University of York, York, UK
2014; Costanza et al. 2017). Valuation of benefits provides policy makers with an understanding of the relative importance placed on different ecosystems. While this is sometimes crudely put as no price means no value and no value means no protection (De Groot et al. 2012), at present the field of ES has vastly expanded beyond ecology and mainstream economics to include broader shared, plural, social, cultural and relational values of nature (Kenter et al. 2011, 2014, 2015, 2016b, 2019; Ives and Kendal 2014; Kenter 2016; Chan et al. 2016, 2018; Costanza et al. 2017; Braat 2018; Stålhammar and Thorén 2019). Recently, the Intergovernmental Panel on Biodiversity and Ecosystem Services (IPBES) introduced the term 'nature's contributions to people' (NCP) to more explicitly encompass relational values than associated with ES (Díaz et al. 2018). Relational values about nature are here considered as values with a relational content, that appreciate relationships between people and 
(elements of) nature, including essential components of a good life (IPBES 2016, Chan et al. 2018).

However, notwithstanding these expansions, the terms ES and NCP still imply a unidirectional value flow; the focus is on nature contributing to people, which disregards values for nature as an end itself and more holistic views on nature-human interrelations (Kenter 2018). Many of the critiques of and resistance to the ES concept in literature and practice are due to the underlying ethical concerns with this focus on human well-being and its inability to encompass intrinsic values (McCauley 2006; Schröter et al. 2014; Cooper et al. 2016). Attempts in environmental economics to acknowledge the value of nature beyond benefits to humans revolve around existence or passive use values (Aldred 1997; Carson et al. 2001). However, in economic theory, existence values are still considered instrumental preferences; it is the (potential for) satisfaction of people's preferences for conservation that is encapsulated within this concept, not the value of nature for its own sake. Moreover, there are still few tools to elicit existence values. The main method is contingent valuation, which similarly relies on instrumental rationality, the limitations of which are widely published (e.g. Aldred 1997; Sagoff 1998; Ravenscroft 2010, 2019; Schröter et al. 2014; Raymond et al. 2014).

Chan et al. (2012, p. 9) note: "As long as non-use, intangible, and cultural values are relegated to an after-thought or poorly represented by ill-suited value metrics, an ES approach will continue to be critiqued by many". Similarly, as long as intrinsic values are insufficiently integrated, valuation of nature will be incomplete, its legitimacy challenged, and the conservation movement hampered by tension between those who advocate instrumental and intrinsic paradigms. Batavia and Nelson (2017) state the importance of recognising intrinsic value because it is: (1) logical, as it is a key reason that conservation exists; (2) practical, because it motivates those who are involved in conservation; and (3) ethical, for we are moral beings.

If these ethical values are not elicited, they may not be considered in subsequent decision-making (Meinard et al. 2016) and as such "it is crucial that ecosystem service valuation provide space for their expression in a manner commensurate with anthropocentric values" (Chan et al. 2012, p. 15).

However, a major challenge is that intrinsic values are typically assumed as an abstract ethical motivation: difficult to elicit, let alone compare with anthropocentric values (Chan et al. 2016). This motivation drives nature conservation as a distinct value stream, and is reflected in an entirely different set of institutions, primarily based on legal implementations (e.g. designation of protected areas, red lists, agreements such as CITES) justified by biological knowledge linked to broad, transcendental ethical values (e.g. protecting biodiversity is good; Meffe and Carroll 1994). This contrasts with the economic, social and cultural domains of instrumental and relational values where social values are derived from the elicitation, aggregation and deliberation of specific, contextual anthropocentric values. These then feed into environmental management policies that may use more flexible mechanisms such as markets in ES, incentive schemes and community planning. This generates important issues: some biological entities are highly protected, sometimes at the cost of basic human needs and rights (UNOHCH 2016), while less auspicious elements of nature are treated as a mere means and may be insufficiently safeguarded.

This calls for better integration of intrinsic with instrumental and relational values in policy and in frames such as that of IPBES. Building on the work of O'Neill (1992, 2001) and O'Neill et al. (2008), this paper seeks to do so by reframing intrinsic value as subjective value-expressions of objective intrinsic value, which we call articulated intrinsic values for ease of reference. We situate articulated intrinsic values in relation to instrumental and particularly relational values, and to an innovative taxonomy that we call the Life Framework of Values, which considers living from, in, with and as the world (Fig. 1). The Life Framework serves to provide an intuitive and inclusive understanding of why the natural world matters, and which is able to effectively integrate ES or NCP and articulated intrinsic values, yet is less abstract and easier to grasp and communicate than the instrumental-relational-intrinsic trifecta as used in reference to ES and NCP. We operationalise our approach through a case study grounded in more-than-human participatory research (MtHPR), which extends participation to the biotic community as a whole, and post-normal science, which advocates extended peer communities for the inclusion and validation of multiple knowledges, values and frames.

This study is, to the best of our knowledge, the first to integrate these two approaches. It further innovates in that it has elaborated the Life Framework from O'Neill et al.'s (2008) original seed, and is the first to operationalise it empirically within a large-scale integrated ecosystem valuation. It is one of the first to empirically examine interrelations between intrinsic and relational values and the first to relate these to the Life Frames. In doing so, we seek to establish a more complete account of the ways in which the more-than-human world matters and provide a more effective theoretical and practical approach whereby different values and motivations for conservation can be considered, communicated and reconciled in sustainability science and governance.

We proceed as follows. Section 2 introduces the Life Framework of Values and explores the different Life Frames in relation to intrinsic, relational and instrumental values, ES and NCP. In Sect. 3, we return to intrinsic values, briefly reviewing its varieties and then developing the concept of articulated intrinsic values as a way to recognise the interests of the more-than-human world alongside benefits of nature 
Fig. 1 The four Life Frames of Values and their relation to the IPBES (2016) categories of intrinsic, instrumental and relational values. $E S$ ecosystem services, $N C P$ nature's contributions to people

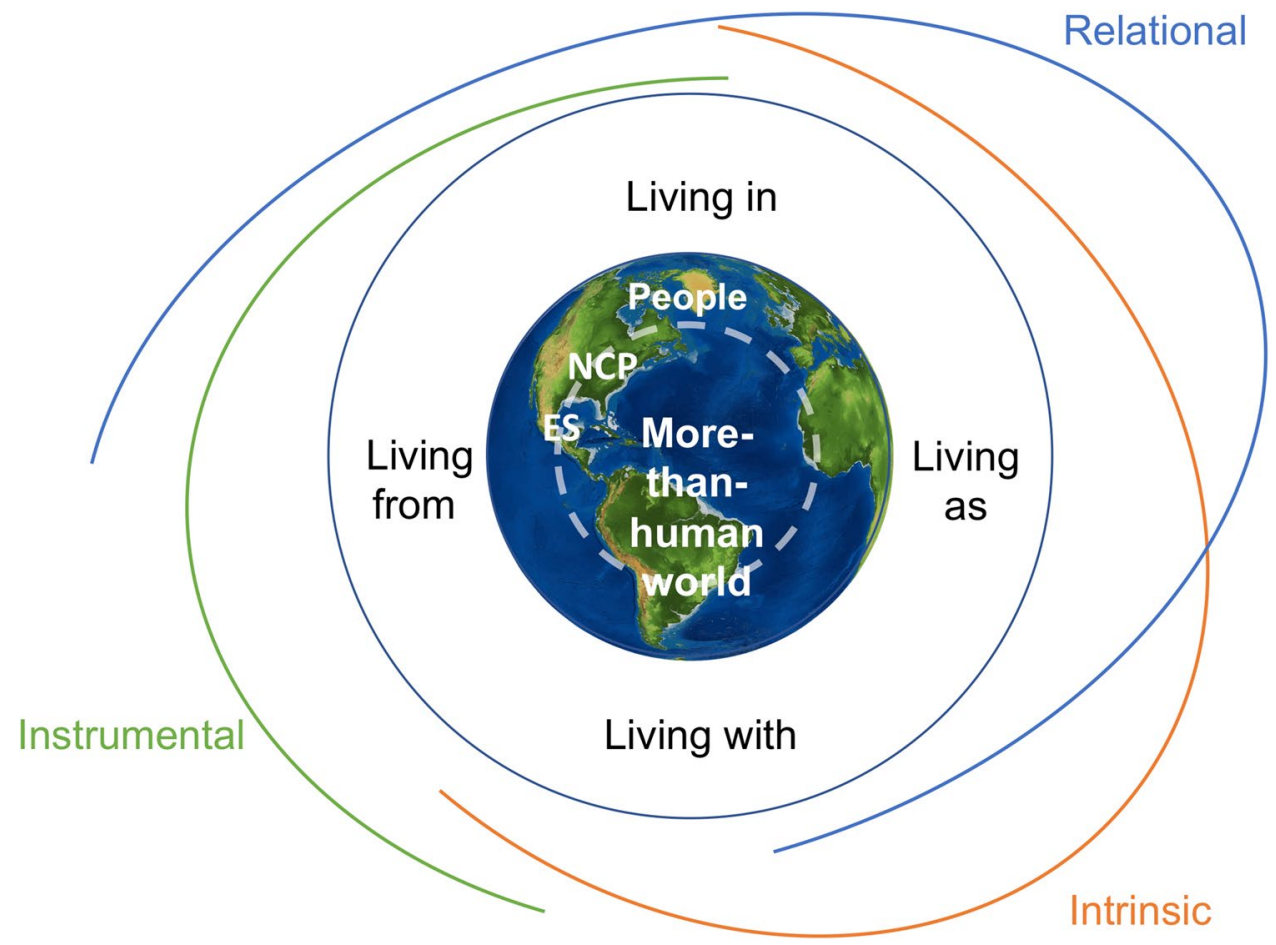

to people. Section 4 operationalises this notion, proposing to extend post-normal and participatory research with the inclusion of more-than-human interests through articulated intrinsic values. We discuss that the emphasis on perspective-taking and deliberation in post-normal and more-thanhuman participatory approaches supports operationalisation of the Life Framework by allowing us to bridge conflicts between the different Life Frames and include multiple knowledges and ethical systems. Section 5 presents a case study where the Life Framework is applied in a large-scale integrated assessment of marine ecosystems and their services. We explore articulated intrinsic values and their coemergence with relational values embedded within each of the Life Frames. Sections 6 and 7 discuss results and draw conclusions, critically reviewing the utility of articulated intrinsic values and the Life Framework of Values as operationalised through the innovative post-normal, more-thanhuman participatory approach.

\section{The Life Framework of Values: living from, in, with and as the world}

Value represents the various ways in which things matter. O'Neill et al. (2008) make three important distinctions in how the environment, nature, or less dualistically, the world, matters to humans. Firstly, how we live from the world, through for example, food and energy - this reflects how the environment matters as a resource, a means to our sustenance. Secondly, how we live in it; this points to the world as a place that is the source or main stage of our life events, from where social and cultural values are born and recreation takes place. Thirdly, how we live with the world; this points to nature or non-humans as important others, who co-exist alongside us, acknowledging that we are one species alongside the larger biotic community living on this planet. We differentiate a fourth category, living as the world, which points to the more-than-human as self, individually and collectively, for example as expressed in indigenous notions of oneness and kinship (e.g. Gould et al. 2019), embodied relational (e.g. Raymond et al. 2017) and phenomenological perspectives of life (e.g. Henry 1963; Ingold 2000), Deep Ecology (e.g. Naess 1988), and nondual spiritual experience (e.g. Wilber 2001). While O'Neill partially considers some of these elements in his discussion of 'in' and 'with', the holism emphasised by the above perspectives prompts us to a distinct category transcending the people-nature duality. Together, we constitute these four frames as the Life Framework of Values of the more-thanhuman world. The more-than-human world is our preferred term to refer to nature inclusive of people and culture, as opposed to the natural environment, non-human nature, or simply nature, as separate from people.

The four Life Frames and the way we conceive their relationship to the IPBES (2016) categories of intrinsic, relational and instrumental justifications of values are depicted in Fig. 1. Something is instrumentally valuable when it is valued as a substitutable means to a human end. Relational 
values are defined as the values relative to the meaningfulness of relationships, including between people and non- or more-than human entities, and the contributions of these relationships to a 'good life'. While relational values are considered as non-instrumental in the sense of non-substitutable and incommensurable with instrumental values, they are still anthropocentric (Chan et al. 2016; IPBES 2016). The intrinsic value of nature in the broadest sense involves the importance of non- or more-than-human entities as an end in itself, rather than as a human end. IPBES (2016) presents multiple conflicting definitions of intrinsic values, defining it both as subjective: "the importance that people believe a thing has unto itself regardless of the interests of people or others"; and also as "objective and inherent properties of an entity or a state of the world properties independent of recognition by humans" (pp. 18-19, emphasis added). We will consider subjective vs objective interpretations in more detail in Sect. 3.

Figure 1 illustrates our conception of intrinsic values as primarily associated with 'living with' but also with 'as' and 'in' frames. Importantly, goods can be valued for more than one reason, and different value types straddle the four value categories rather than map onto them one to one. We will investigate the relations suggested by this diagram further in Sect. 6, aided by case study results.

The Life Framework is also compatible with concepts of ES and NCP (Fig. 2). Different services and contributions can map to more than one frame and the Life Frames encompass more diverse understandings of nature than as a provider of services and contributions to people. However, provisioning services and material contributions can be particularly associated with 'living from', regulating services and contributions with 'living with', and cultural services and non-material contributions with 'living in'. 'Living as' can be associated with some context-specific NCP. Box 1 discusses the relation between the Life and NCP frameworks in more detail.

The intention of the Life Framework is not to abolish decades of thought on accounts of environmental values; rather it is intended as an easy-to-communicate way of typing

\section{Mixed contributions}

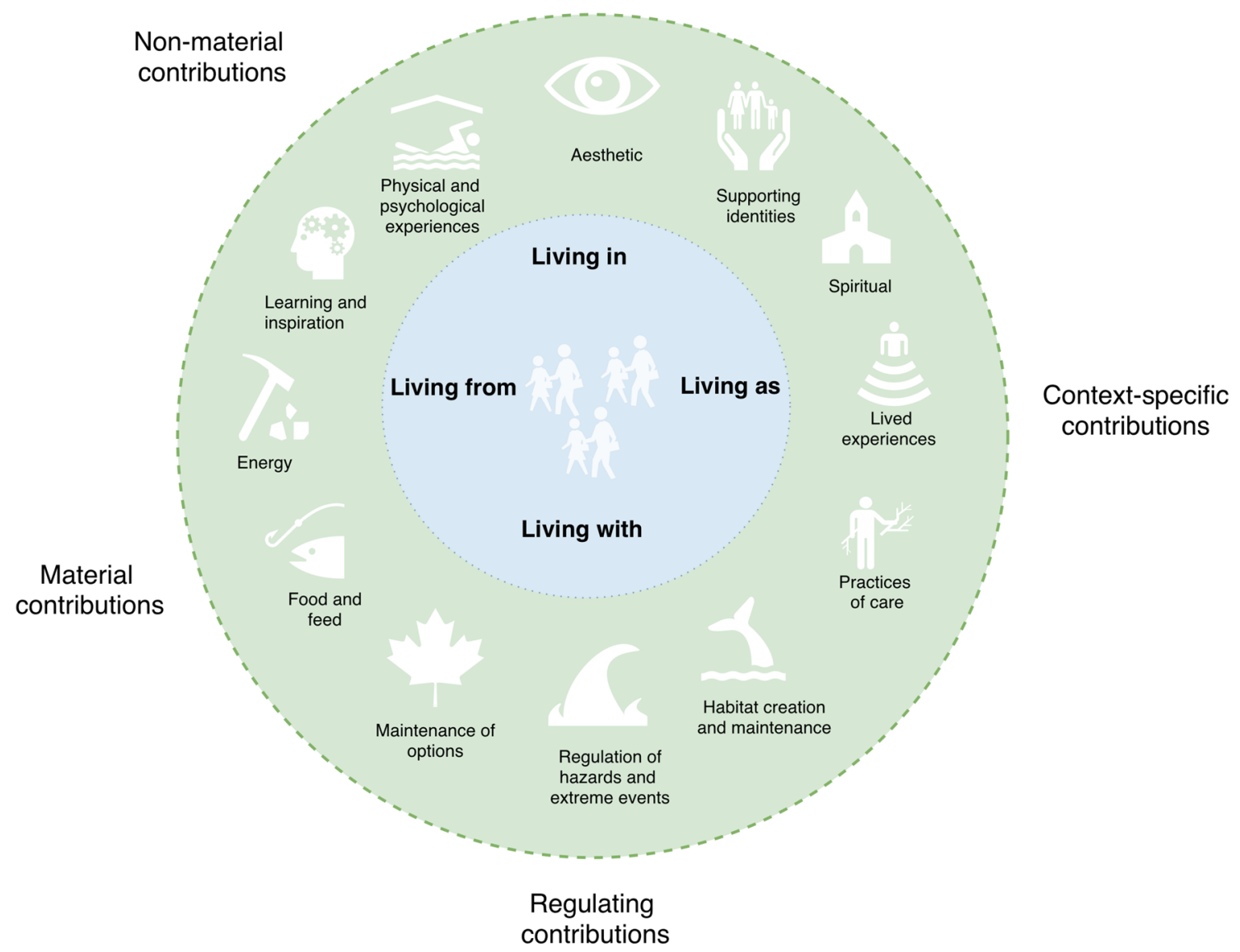

Fig. 2 Examples of how generalised and context-specific nature's contributions to people (NCP; Díaz et al. 2018) can map onto the Life Framework. The four Life Frames are not demarcated as different types and categories of NCP can relate to more than one frame 
Box 1 The Life Framework of Values and the IPBES Nature's Contributions to People framework

Nature's contributions to people (NCP) include ecosystem services (ES) and other conceptualisations of benefits of nature to people, such as nature's gifts (IPBES 2019). The NCP framework (Díaz et al. 2018) considers NCP from two main perspectives: the generalising and the context-specific perspective. This is to provide a system for comparison yet recognise that there is a diversity of context-specific views about how humans engage with nature. Within the generalising perspective, 18 types of NCP are identified within three higher level categories: material, non-material and regulating contributions. IPBES considers three primary justifications for why elements of nature can matter: they have instrumental, relational and intrinsic value (see main text, Sect. 2, for definitions). While intrinsic values are not reflected by NCP, they should nonetheless be considered (Pascual et al. 2017). By defining articulated intrinsic values as without reference to people as valuing agents, they complement NCP and ES, expressed through relational and instrumental values. The Life Framework can be associated with all three value justifications (Fig. 1) and its four frames can be related in various ways to the NCP categories (Fig. 2). However, rather than using a single metaphor for how the nature is important (namely, as contributions to people), the Life Framework more comprehensively considers the ways nature, or less dualistically, the more-than-human world, matters.

Living from points to how we value the world in a provisioning sense but also how it sustains us more broadly. This category spans both the material and non-material contributions that the world makes to humans. This ranges from food consumed and energy produced using natural resources to the learning taken from the environment. These values are predominantly instrumental and relational. For example, fishermen gain both material benefits from their livelihoods and their livelihood is also immaterially constitutive of their quality of life. Maintenance of options (associated with biodiversity option value; Faith 2018) and regulating contributions are important where they underpin our livelihoods and sustenance.

Living with expresses that we share this planet with the more-than-human world, and is enacted in us preserving and creating space dedicated to nature, from spaces for wildlife in gardens to national parks. This frame also most explicitly links to biodiversity and species conservation as an end-in-itself, rather than as a source of NCP. However, it can also be associated with NCP that regulate the environment, such as the regulation of storms and diseases that humans live with. 'Living with' is associated with intrinsic values of non-human nature, relational values insofar as those regulating elements of nature that contribute to our well-being are deemed unsubstitutable, and instrumental values in terms of existence values and where regulating contributions are thought of as substitutable.

Living in can be seen to map on to the non-material contributions of the land- and seascapes that help shape (either socially or physically) how cultures, communities and individuals relate to place, forming and supporting cultural and personal identities. It also maps to material and regulating contributions where they help define the biophysical features contributing to environmental settings. Whereas 'living with' emphasises space for nature, 'living in' is about the importance of nature as place. This frame relates particularly to relational values constitutive of well-being, including aesthetic and spiritual dimensions of places, but also includes instrumental values associated with benefits gained from place-based activities that are amenable to substitution and trade-off, such as many forms of recreation and tourism.

The Living as frame reflects notions and experiences of the more-than-human world, rather than non-human nature. It transcends the ontological or at least semantic dualism of NCP (see Kenter 2018), but can be related to practices of care, kinship and reciprocal relationships between people and the more-than-human. In particular, this frame opens up to lived experiences of the more-than-human world, where activities such as hunting, fishing and outdoor pursuits are experienced as non-separate from nature, and from an embodied perspective (e.g. Ingold 2011). It also reflects diverse spiritual experiences of oneness. This frame primarily embeds relational and intrinsic values. Relational 'living as' values denote that we can value our relations to non-humans and the more-than-human world without this relationship implying that we are separate from them (also see Muraca 2011). 'Living as' intrinsic values acknowledge that the more-than-human world and the non-humans inhabiting it matter for their own purposes regardless of human affairs, yet we experience or see ourselves as an embedded or inseparable part of this community of life.

While intrinsic, reciprocal and nondual values are acknowledged as important by IPBES, the term NCP (like its more established sibling ES) does not reflect these values well, as it implies a one-way street of benefits from nature to people, and a separation between the two (Kenter 2018). IPBES has sought, to some degree, to encompass these values through its context-specific perspective, but these attempts remain constrained by the semantically restrictive heading of NCP. The Life Framework lifts this restriction, and can also more effectively link the generalising perspective and its specific categories to context-specific perspectives, as both generalising and context-specific perspectives can be described through the four basic Life Frames without doing injustice to the diverse ontologies, epistemologies and understandings of values particular to indigenous and local knowledge contexts.

plural values of the more-than human world, that more easily connects with citizens, practitioners and policy makers than more abstract taxonomies of values. Furthermore, phrasing values in relation to 'living' intuitively imbues a sense of egalitarianism between different values and the simple elegance incites a natural inclination towards including each of the categories. As such, it provides a promising framework for better integration of plural values, including intrinsic values, into decisions.

To date, the question of how we value our environment has largely been characterised by a preoccupation with 'living from' the world. This focus continues to attract criticism, including in the way it has dominated the ES agenda (Gunton et al. 2017; Jax et al. 2013; Silvertown 2015; Díaz et al. 2018). Theoretical and methodological advances in our understanding of shared, cultural and relational values associated with ES have sought to better understand our 'living in' the environment, with a growing number of studies using non-monetary valuation methodologies (Scholte et al. 2015; Kenter 2016). However, while relational values are gaining prominence in studying 'living in' frames, many non-monetary approaches still contain an explicit or implicit 
instrumental perspective (Raymond et al. 2014) that limits the breadth of values considered. This adds to ethical concerns over the ability of the ES concept to account for the intrinsic values that might be expressed towards the natural world (Jax et al. 2013). Even in deliberative case studies, non-human considerations can struggle to make it to the table (Orchard-Webb et al. 2016). Furthermore, Comberti et al. (2015) and Cooper et al. (2016) raise important questions about the monodirectionality of the ES framework and note the importance of a two-way flow of value; for example, a gardener might value biodiversity in their garden not just because of benefits such as aesthetic value, but also for them serving the garden. This aligns with the IPBES notion of 'practices of care' that reflect how some people might value a natural landscape (Díaz et al. 2018). However, the IPBES term NCP, like ES, poorly reflects these two-way affairs and values of nature independent of human ends (Kenter 2018).

Such two-way affairs are closely associated with intrinsic values, which are enacted by peoples' concerns for the interests of the more-than-human world and our virtues and duties in relation to non-humans (Cooper et al. 2016). In the next section, we will develop the concept of articulated of intrinsic values and subsequently how it might be operationalised through a post-normal, more-than-human participatory approach, so that intrinsic values can be considered alongside ES and NCP within the Life Framework.

\section{Articulated intrinsic values}

Intrinsic value is an elusive term of which multiple interpretations are easily conflated (O'Neill 1992). To diagnose problems in the way that intrinsic values have been conceived of, we draw on Rawluk et al. (2019) in this special feature, who point out that value concepts can be situated on axes of abstractness and context-dependence. Intrinsic values are often perceived as highly abstract and widely generalisable. For example, it is a common principle of conservation biology that, independent of context, biodiversity is a good in itself (Meffe and Carroll 1994). Such a claim is frequently tied with a moral position ascribing rights to the non-human world (Batavia and Nelson 2017). These approaches underpin much of modern conservation. However, accepting intrinsic values as a categorical imperative can become debilitating; it might lead to implications that unacceptably clash with human needs (O'Neill 1992). For example, around half of protected areas for purposes of nature conservation globally have been established on indigenous territories, and this has frequently entailed expropriation and exclusion (UNOHCR 2016). As such, conservation discourses regularly pit intrinsic values, expressed as rights of non-humans, against human land rights.
At the same time, where intrinsic value is conceived as highly abstract and generalisable, land management may fail to account for it because intrinsic value is seen as inconceivable and impractical (Maguire and Justus 2008). Justus et al. (2009, p. 190) point to the inclusion of intrinsic value as "requiring an as yet undeveloped standard of value analysis for which no convincing methodology has been formulated". Chan et al. (2016) talk of a general aversion to talking about abstract intrinsic values in that they are too philosophical and concept heavy.

Taken together, these concerns are reflective of the dilemma of intrinsic values in way they are often understood - either they are seen as a trump card (potentially used disingenuously; e.g. UNOHCR 2016) or they are excluded from wider land use policy and planning because they cannot be practically operationalized in valuation exercises. Thus, a different approach is needed that considers intrinsic values yet maintains the possibility of comparison with the instrumental values with which they are incommensurable (Chan et al. 2011, 2012; Jax et al. 2013; Martinez-Alier et al. 1998; Meinard et al. 2016). This points to the need for a more context-specific approach for consideration of the more-than-human world.

To achieve this, it is worth briefly exploring how there are multiple conceptions of intrinsic values that range in epistemological assumptions and ethical implications (for more comprehensive reviews, see O'Neill 1992, and Batavia and Nelson 2017). In the most common understanding of intrinsic value within the environmental field, the natural world is seen as valuable in and of itself, independent of its benefit to humans. This non-instrumental value is in addition to its instrumental value, where the world is important as a resource for human purposes.

Intrinsic value can be seen as objective or subjective. The distinction lies in assumptions regarding where the evaluative properties of things reside. Ethical objectivism assumes that they are real properties that exist independently of the valuer, while ethical subjectivism assumes that they are conferred.

'Independent of the valuer' can again be interpreted in two ways: the strong or weak sense (O'Neill 1992). The weak sense suggests that evaluative properties exist even in the absence of the human mind (Rolston 1982); this is the objective intrinsic value definition used by IPBES (2016), but it is a difficult position to maintain (O'Neill et al. 2008; Svoboda 2011). In contrast, in the strong sense, objective intrinsic value means that evaluative properties can be characterised without reference to the (human) valuer (O'Neill 1992). For example, take this statement uttered by a gardener:

' $X$ is good for frogs' 
In this context we can interpret the sense of 'goodness for' in two ways. Either the gardener does not want the frogs and so indicates $\mathrm{X}$ is something that is good at getting rid of them, or, $\mathrm{x}$ is good for frogs in the sense of encouraging a frog's life. In this case the gardener is the valuing agent, yet they consider goodness, or value, from the perspective of the frogs without reference to themselves. The observation of 'goodness for' thus denotes a particular interest as a basis for intrinsic value. However, this does not lead to any conclusion as to how these interests should be regarded-just like diverse human interests, they can be perceived as more or less important and may or may not translate to rights. Just because a pond is good for frogs does not mean we ought to create ponds everywhere. Rather, the implications that follow depend on our moral orientations; we will return to this point in Sect. 4.2.

In contrast to weak objective intrinsic values, strong objective intrinsic values are less abstract and more context-specific in application, they can be readily observed and articulated based on scientific, indigenous or local knowledge and experience. In contrast to subjective intrinsic values, strong objective intrinsic values can be clearly differentiated from relational values. Batavia and Nelson (2017, p. 370) argue that relational values are the "experiential analogues" to subjective intrinsic value. For example, if we express awe or love for nature, this is a form of non-instrumental value that can classify as both subjective intrinsic sensu Callicott (1992), and relational sensu Chan et al. (2018). Thus, for the remainder of this paper, given that non-instrumental relational values are increasingly justified as a value category in their own right (Himes and Muraca 2018), we consider subjective intrinsic values as relational and reserve the term articulated intrinsic values for expressions of objective intrinsic value, which we conceive of in the strong sense.

The appeal then of this understanding of intrinsic value is that it provides a distinct category that informs a contextspecific, practical consideration of the more-than human world, where human and non-human interests can be articulated alongside one another.

\section{Operationalising articulated intrinsic values and the Life Framework}

Thus far, we have considered the Life Framework of Values as an innovative and comprehensive value system that can effectively bring together ES and NCP and their instrumental and relational values, as well as intrinsic values of the morethan-human world. We then presented a strong objective interpretation of intrinsic values, which we call articulated intrinsic values, where values can rest with the non-human world rather than be a wholly anthropogenic affair. However, articulation of such values is subject to interpretation and debate. In this section, we will develop an approach to operationalise articulated intrinsic values alongside NCP and ES within the overarching Life Framework of Values as a vehicle for inclusive integrated valuation. This section will first engage with two important streams of research, which have thus far remained ill-connected: MtHPR (Sect. 4.1) and postnormal science (Sect. 4.2). Both seek to extend sustainability science through participation and deliberation, but in slightly different ways: MtHPR seeks to include the voice of the broader biotic community through participatory approaches, whereas post-normal science seeks to include diverse expert and lay knowledges within an extended peer community to acknowledge the uncertain and normative nature of environmental research. Finally, Sect. 4.3 will argue that, by grounding our operationalisation of articulated intrinsic values and the Life Frames in MtHPR and post-normal science, we do not need to commit to a single ethical system for getting from 'is' to 'ought', and weighing different values against each other.

\section{More-than-human participatory research: including the wider biotic community}

MtHPR is an emerging methodological approach that aims to extend the basic principles of participatory research, such as collaboration and consideration of values from diverse perspectives (Kenter et al. 2016a; Pellizzoni 2003), to include the wider biotic community (Bastian 2017). Bastian (2017) refers to Bergold and Thomas (2012, p. 1), who describe that "the participatory research process enables coresearchers to step back cognitively from familiar routines, forms of interaction, and power relationships in order to fundamentally question and rethink established interpretations of situations and strategies". Building on this basic premise of participatory research, MtHPR encourages us to widen this process by taking on a more-than-human perspective. This aligns with Leopold's motivation for the land ethic, which "enlarges the boundary of the community to include soils, waters, plants, and animals, or collectively: the land" (Leopold 1949, p. 239). More-than-human geographers have described their approaches as encouraging researchers to ask questions of 'what matters' to the more-than-human world (Buller 2015; Hodgetts and Lorimer 2015). The attempt is thus not to confer values onto the more-than human world, but rather to recognise values residing with the more-thanhuman world through participatory research (Warren 1990), thus aligning closely with the notion of articulated intrinsic values. The MtHPR approach also supports operationalisation of Life Framework, because its emphasis on perspective taking allows for recognition of the 'living with' and 'living as' frames which demand us to take on the viewpoints of the biotic community, whether as the other ('living with') 
or as part of an extended self ('living as'). Furthermore, the emphasis of the Life Framework on values as ways of framing what matters means that it invites the kind of articulation of multiple perspectives that participatory approaches can provide.

Where such participation involves deliberation, these approaches often appeal to communicative rationality as an alternative to instrumental rationality (Zografos and Howarth 2010). Habermas describes the aim behind communicative rationality as "a noncoercively unifying, consensus-building force of a discourse in which the participants overcome their at-first subjectively based views in favour of a rationally motivated agreement" (Habermas 1990, p315). MtHPR in this context of communicative rationality navigates the way in which we can articulate both human and more-than-human values in a deliberative setting. The approach answers calls from the fields of nature advocacy and 'green' Habermasian communicative rationality, to bring consideration of the more-than-human world to the forefront of deliberations through representation of nonhuman interests (Dryzek 1990; Eckersley 2011; O’Neill 2001).

\section{Post-normal science: including multiple knowledges and value frames}

Consideration of and deliberation between multiple perspectives is also an important element of post-normal science (Funtowicz and Ravetz 1994; Ainscough et al. 2018). Post-normal science focuses on the principle of quality that incorporates issues of uncertainty, risk and multiple perspectives (Funtowicz and Ravetz 1994; Pellizzoni 2003; Ainscough et al. 2018). Funtowicz and Ravetz (1994, p. 198) describe the principle of quality as enabling us "to manage the irreducible uncertainties and ethical complexities that are central to the resolution of issues in post-normal science. It entails the democratization of knowledge by extension of the peer-community for quality assurance". MtHPR can extend this principle to value articulation with regard to the more-than-human world, potentially altering the way in which familiar human-nature relationships are perceived. This links with the post-normal science position that, at least in relation to complex issues, claims to truth are always limited and value laden (Ainscough et al. 2018). This is because decisions around environmental management involve normative stances on desired outcomes. The post-normal perspective is congruent with the notion of articulated intrinsic values, which although objective in the sense of residing with the object of value, can only be considered through inevitably subjective, perspective-bound articulation. By enabling the articulation of non-human perspectives, albeit through human voice and subjective interpretation, a post-normal, more-than-human participatory approach to valuation can engage with non-humans as co-creators of meaning and value in the world (Batavia and Nelson 2017; Warren 1990).

The post-normal perspective also lends to the assessment and integration of values in accordance with the Life Framework; each frame could invoke different claims to truth and knowledge, constituting multiple valid but incomplete perspectives. The recognition of four distinct frames encourages science-policy-citizen deliberation as to the validity of knowledges associated with each of these frames. For example, the more complete recognition of 'living in' and 'living as' frames in decisions may demand greater integration of humanities, indigenous and local knowledges than has been the case thus far in ecosystem assessment and management. This demands an extension of the peer community, and deliberative democratic rather than technical approaches to the reconciliation of value conflicts.

\section{From 'is' to 'ought': operationalising intrinsic values through plural ethical systems}

Crucially, our reliance on MtHPR and post-normal science for operationalisation of articulated intrinsic values, embedded within the Life Frames, omits both the need to answer the 'demarcation problem' as characterised by debates in philosophy, and to choose between either deontology or consequentialism with regard to moral inclusion of the morethan-human world. The demarcation problem concerns what properties (e.g. life, sentience, self-awareness) should be used to demarcate between what has got intrinsic value and what has not, or to what degree (Muraca 2011). Our approach recognises that people harbour different criteria for demarcation (e.g. distinctness of a species might be considered a criterion for worthiness) and may classify differently according to these criteria (e.g. whether a particular species is distinct or not), and that democratic debate is necessary to address these differences (e.g., to reconcile local or indigenous and western scientific perspectives on how to classify a species, and the ethical implications of this). From this perspective, the demarcation problem cannot be addressed by ethics alone, but may play out differently in diverse and complex practical and political contexts. The Life Frames are important here not in prescribing what values are ultimately prioritised over others, but rather in helping ensure that the multiple ways in which the more-than-human world matters are accounted for and debated.

We also consider the reconciliation of value conflicts, including between articulated intrinsic values and other values, as open to debate, where multiple ethical theories can be appealed to including consequentialism and deontology. Simply articulating an objective intrinsic value may be seen as self-evident, should we not state the implications of how one might act on that articulated value. In Sect. 3, we argued that the common equation of intrinsic values with rights is 
problematic, having led to both human tragedies but also insufficient consideration of the more-than-human world if rights are not ascribed.

O'Neill et al. (2008) suggest an appeal to virtue ethics as a way of moving from 'is' to 'ought', arguing that we should promote the 'goodness for' of non-human life because for us to do so constitutes a good life. This perspective is also found in Leopold's (1949) land ethic, which encourages us to "promote the integrity, stability and beauty of the biotic community" (p. 224). According to Cafaro (2001), Leopold points out that conserving non-human nature helps us become better people (as well as preserving human possibilities). Here, the integrity and stability of the biotic community as a whole helps to guide us in acting on 'goodness for' of its parts. For example, a 'good' gardener might cultivate a patch of land in catering for their own needs (e.g. food, aesthetic pleasure, wellbeing) along with the interests of the more-than-human world in mind; certain wildflowers for bees, a water feature for fish, frogs etc.

However, our operationalisation of articulated intrinsic values also opens the way for consequentialist consideration, where benefits and costs to humans and non-humans can be debated alongside one another. For example, someone might take the view that a particular habitat is 'good for bats' (articulated intrinsic value), but the negative consequences to bats of a wind farm being developed there are outweighed by positive ones to people and indeed other life, by helping to address the climate emergency; or alternatively that bats are so severely declining that costs to bats outweigh the wider benefits. Note that from this perspective, we are not suggesting these different values are commensurable, or even strongly comparable (Martinez-Alier et al. 1998, 1999); rather, that democratic debate may acknowledge and consider consequences to non-humans without reference to rights.

While virtue ethics and consequentialism can thus provide pragmatic and context-specific enactment of articulated intrinsic values, articulation of intrinsic value can also be directly coupled to articulation of rights. For example, Dongria Kondh in Orissa, India, have opposed bauxite mining of Nyamgiri mountains because mining crosses the interest of the mountains themselves, which are seen as alive and sacred, and their rights of protection to be inviolable (Temper and Martinez-Alier 2013).

As such, it is not our purpose here to advocate a single approach to arriving at moral claims; a strong objective concept of intrinsic values provides advantages regardless of whether one takes a virtue-based, consequentialist, deontological or other ethical approach (O'Neill 1992). Articulation of intrinsic values may then be considered through recognising the weak comparability of plural values, which forms the bedrock of deliberative democracy and deliberative ecological economics (Martinez-Alier et al.
1998). Post-normal science underpins the acknowledgment of this plurality while MtHPR opens up a space to draw out articulated intrinsic values, and the Life Frames provide a vehicle for integrating and accessing them along with instrumental and relational values in an easily communicable way.

\section{Case study: integrated valuation of marine ecosystems}

We applied the Life Framework-based, post-normal, morethan-human participatory approach in an integrated valuation as part of the large-scale UK Marine Ecosystems Research Programme (MERP). The valuation included coupled ecological-economic modelling of the impacts of a number of hypothetical social-ecological scenarios on marine ecosystems and their services (Kenter et al. forthcoming), plus qualitative cultural work (Ainsworth et al. 2019) in two large-scale case regions: the West Coast of Scotland and the South West of England. The scenarios were co-developed with stakeholders and their impacts collectively deliberated, weighing the diverse values that arose from the different research strands, including articulated intrinsic values, to form shared social values around different marine policy options. Here we focus on the predeliberative, qualitative work which focused on articulating intrinsic and relational values within the different Life Frames. Our motivation for the focus on intrinsic and relational values was firstly that within the overall valuation, instrumental values were well-represented by elaborate modelling approaches focused on instrumental values of ES, and secondly that while the difference between instrumental and intrinsic values is well-established, the relation between intrinsic and relational values is a matter of recent debate (Batavia and Nelson 2017; Stålhammar and Thorén 2019; Kenter et al. 2019) and has seen little empirical investigation (Klain et al. 2017).

Forty stakeholders were identified and invited to participate in a video-recorded interview. Sampling was purposive to represent a broad cross-section of marine stakeholders. Participants were selected from a comprehensive list of 289 stakeholder organisations and groups compiled from previous research, plus snowball sampling. Participant selection was informed by an influence-interest matrix. Participants were particularly targeted with high levels of interest but low levels of influence in marine management decisions, reflecting deliberative-democratic inclusivity aims (Tewdwr-Jones and Allmendinger 1998; Kenter et al. 2016c). Table 1 lists participants and their sectors.

Following Ranger et al. (2016), recordings were compiled in a documentary film that provided the vehicle for transmitting value expressions to the subsequent deliberative group and wider audience in an efficient and accessible format. The 
Table 1 Sample of stakeholders by sector and respective backgrounds
Table 2 Prompt questions to encourage consideration of the more-than-human perspective

\begin{tabular}{|c|c|c|c|c|}
\hline Primary sector & No. of participants & Secondary sector & & No. of participants \\
\hline \multirow[t]{5}{*}{ Provisioning } & \multirow[t]{5}{*}{15} & \multirow[t]{3}{*}{ Gear types } & Hand & 2 \\
\hline & & & Static & 4 \\
\hline & & & Mobile & 1 \\
\hline & & Fisheries & & 4 \\
\hline & & Aquaculture & & 4 \\
\hline \multirow[t]{4}{*}{ Regulatory } & \multirow[t]{4}{*}{12} & NGO & & 6 \\
\hline & & Government & & 3 \\
\hline & & Research & & 1 \\
\hline & & Strategic partnerships & & 2 \\
\hline \multirow{3}{*}{$\begin{array}{l}\text { Tourism, leisure, } \\
\text { recreation }\end{array}$} & \multirow[t]{3}{*}{11} & Diving & & 2 \\
\hline & & $\begin{array}{l}\text { Angling (charter boat } \\
\text { fishing) }\end{array}$ & & 4 \\
\hline & & $\begin{array}{l}\text { Wildlife (general) tour- } \\
\text { ism }\end{array}$ & & 5 \\
\hline Local residents & 2 & & & \\
\hline
\end{tabular}

Question

\begin{tabular}{l}
\hline How could we better represent the interests of marine species and habitats in this area \\
within management decisions? \\
$5 \mathrm{f}) \quad$ What management outcomes would most benefit marine species and habitats in this area?
\end{tabular}

interview script, presented in more detail by Ainsworth et al. (2019), was structured around key themes identified for the larger purpose of the MERP project relating to understanding respondents' activities, experiences, identities, capacities and values and how these might be affected by potential changes in the marine environment under the different scenarios. To specifically prompt participants to articulate intrinsic values, two questions were included to encourage consideration of the more-than human perspective (Table 2).

\section{Analysis}

Interviews were transcribed and analysed using Nvivo 11 (QSR International). The analysis adopted a theory-driven approach (Bryman 2008). The codebook built on the IPBES general framework (Díaz et al. 2015; the most recent version at the time) and UK National Ecosystem Assessment framework for cultural ES (Church et al. 2014; Fish et al. 2016). We added two intrinsic value codes to investigate the research questions explored here: the first denoting intrinsic value as non-instrumental value broadly, including subjective and objective conceptions and references to rights that might imply either. The second was a more focused daughter-code for articulated intrinsic values, which categorised specific examples of statements that could be characterised without reference to the evaluating agent, where participants explicitly described non-human interests and ends or articulated non-human perspectives. We investigated the co-emergence between these categories and relational values. The latter were indicated by two codes derived from the IPBES framework: 'relationship with Mother Earth' and 'interdependence among human beings, other living species and the elements of nature'. Further, we considered whether the more-than-human prompts led to an increase in references to articulated intrinsic and/or relational value codes.

Finally, to examine how articulated intrinsic values and relational values mapped on to the Life Framework, four daughter codes reflecting the Life Frames were added to each of these codes for articulated intrinsic and relational values. Two researchers coded the data and four inter-coder reliability tests were carried out (Table 3), suggesting substantial level of agreement between coders. To resolve disagreements, the coders clarified terms and discussed differences in coding approaches and shared techniques for the remainder of the coding process.

Table 3 Kappa scores for the four interviews where intercoder reliability tests were undertaken

\begin{tabular}{ll}
\hline Participant & Kappa \\
\hline P\#10WCOS & 0.764 \\
R\#11WCOS & 0.620 \\
P\#1SW & 0.698 \\
R\#4SW & 0.734 \\
\hline
\end{tabular}

Scores $>0.6$ indicate substantial agreement (Landis and Koch 1977) 


\section{Results}

The code 'non-instrumental value' was referenced at 146 points in the data and examples were cited in 30 of 40 interviews. 'Articulated intrinsic value' made up 91 of these references across 27 sources. The points of difference between articulated intrinsic values and other non-instrumental values were reflected in people talking of nature's right to exist or in describing nature simply as 'invaluable', but without a clear example of value characterised without reference to people. Articulated intrinsic values were prevalent across the vast majority of regulatory $(79 \%)$, tourism $(70 \%)$ and local resident (100\%) participants, but less prevalent with the provisioning sector (46\%) (Table 4). Participants regularly took on non-human perspectives, as seen in quote A (Table 5), where the participant talked of the limpets as a "window into another world" before asking what it might be like to be them, and quote $\mathrm{D}$, where a diver talks of having a peek into another world where things play out as if they weren't even there.

In terms of the Life Framework, there were examples of 'living with', in' and 'as' throughout the intrinsic and relational values data. Of the 91 articulated intrinsic value examples, 60 references provided examples of 'living with'. There were 17 references to 'living as'; for example, quote B pointed to a holistic systems perspective of ecosystem interactions, living as part of the web of life. There were 13 references to 'living in', exemplified by quote $\mathrm{D}$, where the marine environment is set as a stage for recreation (diving). There was only one reference to articulated intrinsic value relating to 'living from', quote $\mathrm{E}$, which recognised conflict between the good for a harbour and the species landed.

The more-than-human prompts did not increase articulated intrinsic values, with 57 references across 20 interviews before the prompts and 34 references after.

There were many examples of relational values, with 162 references made across 36 of the interviews to 'interdependence among human beings, other living species and the elements of nature' and 139 references across 36 interviews to 'relationship with Mother Earth'. These codes were not mutually exclusive, with the aggregate number of relational value references being 274 across 38 of 40 sources. There was no overlap between articulated intrinsic and relational value codes, but 14 relational value references were coded as other non-instrumental values, where for example participants described love for the wildlife and places they lived in.

Examples of references to the relational codes ranged from participants talking about how the natural environment made them feel to how they perceived the role of people in nature (Table 6). In terms of the Life Framework, of the 162 'interdependence' references, 69 were coded as examples of 'living in', 43 as 'living with', 34 as 'living as' and 16 as 'living from'. 54 of the 'relationship with Mother

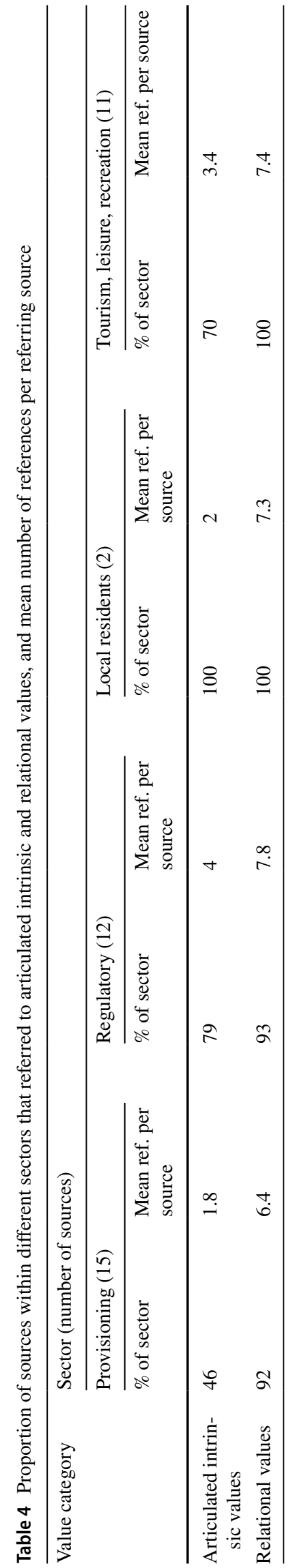


Table 5 Examples of articulated intrinsic values with associated categories of the Life Framework of Values

\begin{tabular}{|c|c|c|c|}
\hline Participant sector & Quote & Example of articulated intrinsic value & Life Frame \\
\hline Regulatory & A & $\begin{array}{l}\text { I feel these places are precious, they are windows on a world that is terribly important to } \\
\text { us, that we totally overlook... If you think of yourself as one of these, you can ask a kid } \\
\text { to think of itself as a limpet, and they start to think about, How does it feed? How far is } \\
\text { it moving? How does it feel when I knock it off a rock? }\end{array}$ & Living with \\
\hline Provisioning & $\mathrm{B}$ & $\begin{array}{l}\text { You know, we're not just looking at sea here, we're looking at runoff, and we're looking } \\
\text { at, you know, reforestation and everything to support an environment, because we're } \\
\text { starting to look at a bigger picture that is the planet, and that is a single organism, and } \\
\text { you can't say that the bee does not belong to the flower, it's the same organism, it's just } \\
\text { the bee does something else, and eventually will come and meet the flower, but that } \\
\text { whole system is of something much bigger. And then all of a sudden, we think actually } \\
\text { I'm part of something, too, you know. And I like it }\end{array}$ & Living as \\
\hline Tourism, leisure, recreation & $\mathrm{C}$ & $\begin{array}{l}\text { I think really and in many ways you've gotta explain to people, these animals don't think } \\
\text { like human beings... They can react in totally different ways, mainly that they're act- } \\
\text { ing as a community, their own way, they're fishing and everything and just trying to } \\
\text { explain to people that they're wild, they're wild animals and not trying to control them } \\
\text { but we've gotta control ourselves and give them maybe a bit more freedom to do what } \\
\text { they wanna do }\end{array}$ & Living with \\
\hline Tourism, leisure, recreation & $\mathrm{D}$ & $\begin{array}{l}\text { I felt that we weren't intruding in, we aren't impacting on their environment really. Yeah, } \\
\text { that was great, we've had flocks of gannets diving all around the boat, ya know, loads } \\
\text { of 'em. Well over 50, } 60 \text { gannets just... start diving into shoals of fish and then we've } \\
\text { been through a pod of common dolphins and we've literally looked around on a flat, } \\
\text { calm day and you can see well over } 100 \text { dolphins, further out, some fishing, some bow } \\
\text { riding with us, others just fishing in groups and when they're fishing, dolphins, they've } \\
\text { not got an interest (in what we're doing) }\end{array}$ & Living in \\
\hline Regulatory & $\mathrm{E}$ & $\begin{array}{l}\text { We'll get } 10,000 \text { boxes of squid in the next } 3 \text { weeks, which is fantastic for the harbour's } \\
\text { bank account but it's not great for the squid }\end{array}$ & Living from \\
\hline
\end{tabular}

Table 6 Examples of relational values with associated categories of the Life Framework of Values

\begin{tabular}{|c|c|c|c|}
\hline Participant sector & Quote & Example of relational value & Life Frame \\
\hline Provisioning & A & $\begin{array}{l}\text { That is really brought home to you when you're in that environment, cause there's not } \\
\text { really all the distractions and trappings of modern life which kind of cover that up. It's } \\
\text { very clear to see that out there. It's probably why I go out there, to clear my head from } \\
\text { a lot of the stuff that goes on here. It makes it much more understandable, simple }\end{array}$ & Living in \\
\hline Regulatory & $\mathrm{B}$ & $\begin{array}{l}\text { I find it very relaxing being in the sea. I find it nicer to be in the sea than not. So that's } \\
\text { why a lot of my leisure activity is based around being in the water. And, you know } \\
\text { two weekends ago we were paddle boarding with porpoises in the surf with us. So that } \\
\text { makes a difference about how you feel about somewhere as well as when you can have } \\
\text { that kind of interaction with wildlife; that kind of stuff without having the impact on } \\
\text { them during that point }\end{array}$ & Living in \\
\hline Local Resident & $\mathrm{C}$ & $\begin{array}{l}\text { To try and pinpoint any one place and say that's more special than another is impossible } \\
\text { because they're all special for different reasons. There's fantastic colonies of birds } \\
\text { on some of these islands which rely on the sand eels and it's amazing to watch them. } \\
\text { There's nothing quite like watching a gannet dropping straight out of the sky like an } \\
\text { arrow into the water to catch fish. It's just unbelievable. And it is a very good place to } \\
\text { live because sea eagles live here too, they rely on the fish }\end{array}$ & Living with \\
\hline Tourism, leisure, recreation & $\mathrm{D}$ & $\begin{array}{l}\text { But you're actually being out there, participating, actually being out there in nature, } \\
\text { experiencing the weather and the environment as its best, an at its worst of course. You } \\
\text { don't know what you're gonna catch which is part of the excitement }\end{array}$ & Living as \\
\hline Provisioning & $\mathrm{E}$ & $\begin{array}{l}\text { I'm the seventh generation to live in the house. I don't say they've all been fishermen, } \\
\text { but my dad certainly was, and I know my great grandfather had a boat and used to put } \\
\text { a few pots out and row people around the bay. It's just something I feel we've always } \\
\text { done. And I've always done it from a very small child... It's a shame dad's not around } \\
\text { to hear that, but it does make me smile }\end{array}$ & Living from \\
\hline
\end{tabular}


Fig. 3 Proportion of references to articulated intrinsic and relational values associated with different Life frames

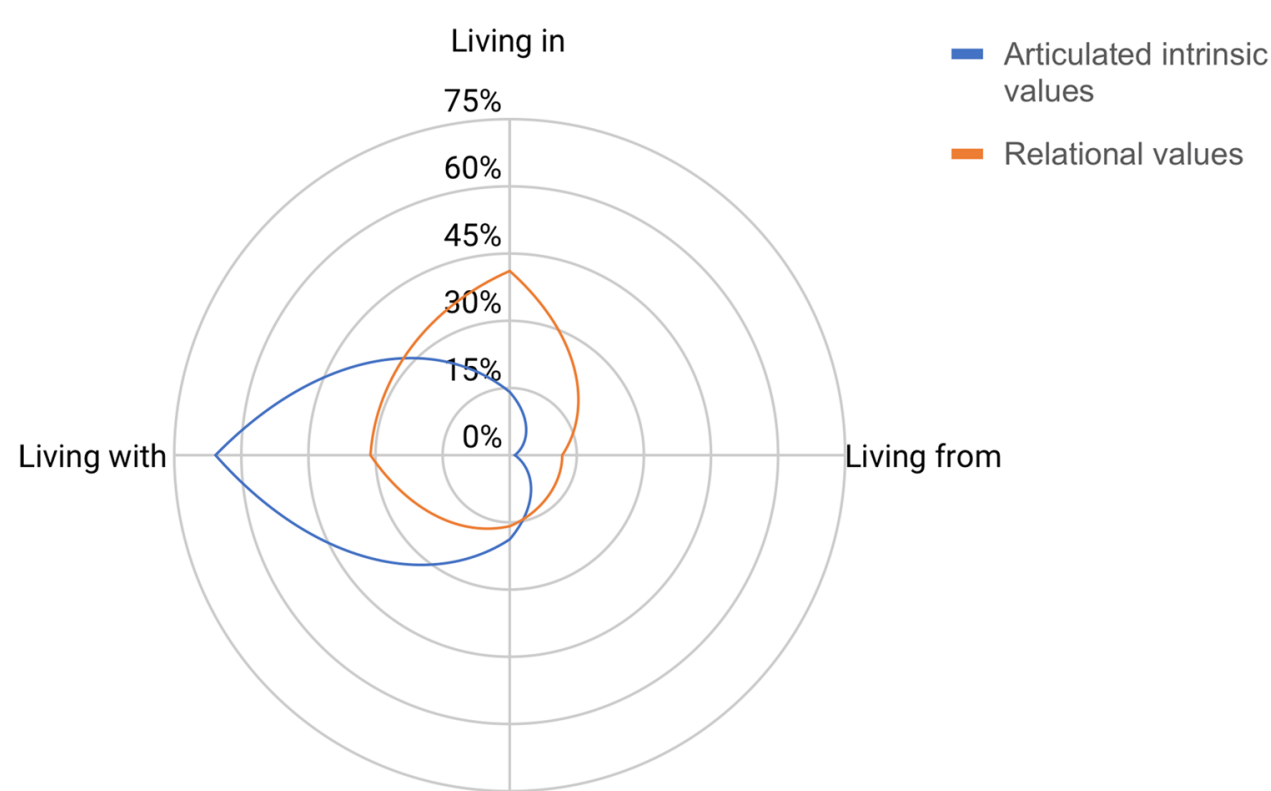

Living as
Earth' references related to 'living in', 49 to 'living with', 22 to 'living from' and 14 to 'living as' (Fig. 3). Expressions of 'living in' related to therapeutic benefits of being in and on the sea and interacting with wildlife (quotes A-B). Relational values associated with 'living with' expressed love, awe and amazement with observing other species and places (quote C). Relational values in the 'living as' frame related not to observing but participating in nature, being a part of it in close relation with the elements (quote D). Relational values associated with 'living from' considered fishing as part of one's identity (quote E) or with aquaculture as a form of animal husbandry rather than purely instrumental production.

Following the prompts, the number of sources and references to the 'interdependence' code substantially increased (from 17 to 34 sources and 40 to 94 references). There was a proportionally smaller increase at the 'relationship with Mother Earth' code (from 28 to 33 sources and 61 to 72 references).

\section{Discussion}

Our case was the first empirical study to apply the Life Framework of Values, operationalised through a post-normal, more-than-human participatory approach. Pre-deliberative qualitative work within a larger integrated valuation of marine ecosystems specifically focused on articulated intrinsic values, their differences and associations with relational values, and how they might co-emerge within the different Life Frames.
The substantial number of sources referring to articulated intrinsic values throughout the interviews suggests our approach was successful in allowing a space for their expression. Articulated intrinsic values were expressed in ways that allowed them to be considered and deliberated alongside anthropocentric instrumental and relational values. For example, Table 5, D, reflects how recreationists consider wildlife by taking on the perspective of dolphins and gannets. This context-specific consideration of the more-than human world does not suggest a no-go zone in the area that might be ensued by more abstract notions of intrinsic value. Rather, it recognises perspectives and interests without reference to people as valuers, expanding our 'ethical envelope' (Everard et al. 2016), but in a way that can be compared to benefits to people. As such, our approach, where diverse stakeholders, informed by their local knowledge, were able to articulate intrinsic alongside relational and instrumental values across the different Life Frames, aligns with the post-normal call to extend the peer community, democratise knowledge and values and more inclusively face ethical complexities of environmental issues (Funtowicz and Ravetz 1994).

There were substantially more expressions of noninstrumental values as such interests and perspectives than as other non-instrumental value statements. This pointed to a preference for expressing context-specific observations as opposed to more abstract notions of intrinsic values like assignments of context-independent rights. For example, in Table 5, C, a respondent talks about how particular species act in particular ways of their own, and we should "...give them maybe a bit more freedom to do 
what they wanna do". The articulated intrinsic value is expressed by the participant as a description of goodness for the species they are talking about independent of people, followed by an ought-statement noting that we should let them seek that good.

\section{Intrinsic and relational values}

Our expectation was that explicitly prompting for consideration of 'goodness for' the more-than-human world would bring out articulated intrinsic values more directly and specifically. This was not the case, as it appeared that such values were already prominent and explicit. More curious was the substantial increase in relational values following the prompts. Perhaps, if non-human interests had already been articulated, prompting for them might have encouraged respondents to reflect more on their relations and interdependence with marine life rather than rather than to rearticulate previously expressed non-human interests. Indeed the results displayed a strong co-emergence of articulated intrinsic and relational values. This reflects that participants may observe objective evaluative properties of non-human entities without reference to people, and at the same time relate to these entitities more subjectively, giving expression to their own feelings and experiences. While these may be two sides of a coin, they paint a different picture. For example, Table 6, comment C, seems similar to Table 5, comment $\mathrm{D}$, where both describe being in the presence of birds feeding. However, the former talks of how "it's amazing to watch them" and how "it's a very good place to live because", indicating the relational quality of the species and habitats with regard to the participant's own experiences, whereas in the latter, the focus is on the perspective of gannets and dolphins and how they are doing something irrespective of human observation. This example illustrates how articulated intrinsic values are closely associated with perspective-taking, articulated by the participant stating that animals have not got an interest in what people are doing, but are "acting in their own way". This quote articulates intrinsic value not through a specific interest (e.g. fishing nets are not good for dolphins) but reveals a recognition by the respondent that animals seek a good of their own, reflecting that they have interests independent of humans and that these need to be taken into account.

Thus, the quotes in Tables 5 and 6 illustrate how the coemergence of relational and intrinsic values was embedded in narratives, eventful stories about the environment where the narrator alternates as observer of the environment ('living with'), subject on the environmental stage ('living in'), participant in the web of life ('living as'), and beneficiary of its resources ('living from'). O'Neill et al. (2008) points out that narratives intimately mix descriptive and normative content. The normative content of narratives is not always easily characterised in conventional consequentialist, deontological and virtue terms, with evaluations often implicit from the way the story is structured and told, and different value justifications intermingled. This is also evidenced by recent work on cultural ES valuation. Stålhammar and Pedersen (2017) noted that their participants found it difficult to describe their values when identified as axiological types. More often, values were expressed in discussions about relationships with nature and understanding how these experiences made them feel. Kenter et al. (2016a) used a narrative-based approach as part of an integrated valuation with marine recreationalists. It appears from their results that relational expressions of place identity gave rise to articulation of intrinsic values, and vice versa.

Given that our definition of articulated intrinsic values allowed for a clear distinction with relational values, no references were coded to both. However, the broader understanding of intrinsic values as non-instrumental overlapped with relational values in various cases of subjective intrinsic values sensu Callicott (1992), such as love and amazement. This supports that relational values as 'experiential analogues' can be entangled with notions of the intrinsic worth of non-humans (Batavia and Nelson 2017; Stålhammar and Thorén 2019).

These results make sense, as it appears unintuitive to value something without having any form of relationship with it. This relationship can be direct, as for example in a Hawaiian case described in rich detail in this special feature by Gould et al. (2019), but could also be quite indirect. For example, those in the west who value tropical rainforest are likely to still feel some sense of emotional connection with the object of value, through holistic concepts such as 'mother earth' or through media such as nature documentaries. Relational values may also explain the economic concept of 'warm glow' (Becker 1974) that economists use to re-classify other-regarding values as utility to oneself (Carson et al. 2001).

This discussion raises the question of why we should specifically seek out intrinsic values if so often they appear to associate with relational ones. There are at least two reasons: (1) doing so explicitly acknowledges the procedural justness of including goodness-for the more-than human world; (2) not all methods that seek to assess relational values may also articulate intrinsic values.

As to the first, subjective intrinsic values may be embedded within relational values such as place attachment and cultural identities. However, we have evidenced that articulated intrinsic values can be clearly distinguished. While relational values may well be non-instrumental in the sense of denoting the importance of relationships that are an end in themselves and/or not substitutable (Himes and Muraca 2018), they are still anthropocentric. If intrinsic values are not distinctly articulated and presented, there is a clear risk 
that non-human perspectives are insufficiently included within consequent deliberations and decisions (Piccolo 2017). For example, Orchard-Webb et al. (2016) pointed out that in their deliberative democratic monetary valuation, they were unable to effectively include more-than-human considerations, because nobody within their group of deliberators was charged with this perspective. To achieve procedural justice and 'green' deliberative democracy (AriasMaldonado 2007; Dryzek 1990; Eckersley 2011), we need to operationalise intrinsic values in such 'new democratic spaces' (Irvine et al. 2016; Kenter 2016), and this can be effectively achieved through articulation of 'goodness for' the more-than-human by taking on non-human perspectives.

Second, not all understandings of relational values or methods to assess them accommodate articulated intrinsic values. For example, some of the originators of the relational values term within the field of ecosystems knowledge recently applied a quantitative psychological indicator-based approach (Klain et al. 2017). The successful study helped clarify social-psychological relational values, but did not rhyme with articulated intrinsic values in terms of either value types or epistemological assumptions. The authors distinguished relational values from a more established category, biospheric values, but biospheric values in the socialpsychological sense do not equate with intrinsic values; they are a transcendental values category, reflecting people's broad pro-biosphere principles, such as seeking harmony with nature. In contrast, as discussed in Sect. 3, articulated intrinsic values are fundamentally contextual rather than transcendental, associated with specific objects of value (see Kenter et al. 2015, 2019; Raymond and Kenter 2016 for discussion of these terms); in this study, for example, gannets and limpets were seen to hold intrinsic value. In terms of epistemological assumptions, the post-normal approach that we ground articulated intrinsic values in assumes that, even whilst intrinsic values are associated with objective properties that can be studied using scientific methods, their articulation is ultimately subjective, and metric-based approaches are on their own insufficient to reflect them. Articulated intrinsic values involve perspective taking; to understand these perspectives a discursive approach is necessary such as the interpretive-deliberative approach presented here.

\section{Value of the Life Framework to environmental governance}

Such a discursive approach naturally gives rises to questions of how people frame the more-than-human world in relation to themselves. Our case results showed that the different stakeholder groups all valued the marine environment in multiple ways, each of which spanned multiple Life Frames of value. For example, the quote from Table 6 , C points to the value of 'living with' the natural world, through the sharing of a place with other species, Table 5 , D points to the value of 'living in' it, with the natural world being the stage for a tourist activity. This denotes the importance of recognising that both relational and articulated intrinsic values can be associated with a frame of nature out there to be preserved or a sense of the natural world as our life stage (Figs. 1, 3). Both can also sit within a 'living as' frame, articulating a sense of being part of nature (Tables 5, B; 6, D). Crucially, while more intrinsic and relational values came from the regulatory sector, provisioning stakeholders also talked about 'living with', 'in' and 'as' the world, not just 'living from'.

The ability of Life Frames to cross different interests makes the framework a boon in environmental governance, particularly with regard to participatory approaches. Acknowledging the validity and complementarity of easily communicable value frames allows for an approach that is both comprehensive and inclusive, but moreover an avenue for identifying shared values where there are conflicts. Furthermore, our discussion of the co-emergence between context-specific, articulated intrinsic and relational values highlights the value of the Life Framework as a less abstract approach to values, as the often-nuanced differences between relational and articulated intrinsic values may be neither evident nor particularly relevant to practitioners. While environmental justice demands the inclusion of non-human perspectives and interests within our policy deliberations, structuring such deliberations according to the Life Frames could provide a more effective vehicle for characterising value conflicts and addressing value plurality in sustainability policy and practice than by using the instrumental-relational-intrinsic trifecta.

Our addition of 'living as' to O'Neill et al.'s (2008) original three ways in which they recognised that the more-thanhuman world matters, provided an important, distinct category, incorporating a sense of wholeness (e.g. Table 5, B) and value arising from "lived experience" (Díaz et al. 2018, p. 17) as exemplified by Table 6 , D. The frame is important in allowing for the articulation and expression of these value types in ways that are conceptually and experientially less dualistic and more embodied. 'Living as' was associated with articulated intrinsic values and relational values alike. 'Living as' intrinsic values reflect that nature has its own purposes, yet we experience or see ourselves as an embedded or inseparable part of this picture. 'Living as' relational values express that we can relate to the non- and morethan-human, without this relationship implying two that are bounded ontologically. This corresponds to Muraca's (2011) conception of relationships as ontologically constitutive to entities engaged in them: we are defined by these relationships. The recognition of these values in our case study suggests that such non-dual values are not only found in indigenous experience, Deep Ecology and spiritual traditions such 
as Sufism, Hinduism and Buddhism, but could in fact be ubiquitous 'on the ground' in diverse contexts where people ‘dwell' (Ingold 2000) in nature.

\section{Conclusions}

Democratic debate and decision-making entails weighing the often-conflicting values, interests and purposes of diverse stakeholders. The deliberative turn (Rodela 2012) and increased attention to post-normal approaches in ecosystem management (Ainscough et al. 2018) has meant increased attention to justice with regard to whose values are considered and whose voice is heard (Kenter et al. 2019). Articulating the interests of non-humans has a long history (e.g. Stone 1972), but is now particularly salient given the increasing emphasis on nature as service provider and contributor to human well-being. By considering intrinsic values as context-specific, subjective articulations of objective evaluative properties, the interests and perspectives of non-human stakeholders can be directly expressed alongside those of human ones. Instead of as abstract phenomena, intrinsic values can be operationalised as debatable propositions of 'goodness for', which can be given normative weight according to the goals we seek as a democratic society. This way, social values of ecosystems can be extended to the more-than-human, addressing important ethical concerns with the ES framework (Jax et al. 2013; Silvertown 2015).

While we have demonstrated how it is possible to practically extend $\mathrm{ES}$ or NCP approaches by combining them with articulated intrinsic values, it is not possible to fully reflect intrinsic values within them, as services and contributions to people by definition exclude values without reference to human beings. However, our case results suggest that articulated values were nonetheless intimately intertwined with relational values to people. A better understanding of the associations between the two is an important area for future research. Intrinsic and relational values of nature can be considered two sides of a coin, yet intrinsic values need to be distinctly articulated to ensure the recognition of unique non-human perspectives, which need their own representation at the values table.

The recognition of diverse values within multiple value frames-living from, with, in and as the world-provides a nuanced approach to understanding these perspectives and relating them to an easy to understand and communicate taxonomy of why the more-than-human world matters. The intuitive simplicity and comprehensiveness of the Life Framework provides an avenue for enhancing inclusivity and transcending the one-sidedness and anthropocentrism of ES and NCP. When we recognise that, regardless of background, stakeholders typically harbour and express more than one Life Frame, this defies stereotyping stakeholders according to their narrow interests and allows the Life Framework to become an effective tool for better recognising each other's perspectives and experiences, and finding shared social values for sustainability. Further research might investigate how the Life Frames are responded to by different decision makers and stakeholders when presented with them more explicitly, and how the Life Framework can be used as a way of framing valuation beyond ES and NCP and as a vehicle for navigating environmental conflicts.

Acknowledgements We thank Gill Ainsworth who greatly assisted in the qualitative data collection and analysis, the case study participants, and two anonymous reviewers whose comments greatly helped improve the manuscript. This research was funded by the UK Natural Environment Research Council (NERC) and the Department for Environment, Food and Rural Affairs (Defra) as part of the UK Marine Ecosystems Research Programme (Grant reference NE/L003058/1).

Open Access This article is distributed under the terms of the Creative Commons Attribution 4.0 International License (http://creativeco mmons.org/licenses/by/4.0/), which permits unrestricted use, distribution, and reproduction in any medium, provided you give appropriate credit to the original author(s) and the source, provide a link to the Creative Commons license, and indicate if changes were made.

\section{References}

Ainscough J, Wilson M, Kenter JO (2018) Ecosystem services as a post-normal field of science. Ecosyst Serv 31:93-101. https://doi. org/10.1016/j.ecoser.2018.03.021

Ainsworth GB, Kenter JO, O’Connor S, Daunt FJH, Young JC (2019) A fulfilled human life: sense of place and cultural identity in the marine environment. Ecosyst Serv (under review)

Aldred J (1997) Existence value, moral commitments and in-kind valuation. In: Foster J (ed) Valuing nature? Economics, ethics and environment. Routledge, London

Arias-Maldonado M (2007) An imaginary solution? The green defence of deliberative democracy. Environ Values 1:233-252

Bastian M (2017) Towards a More-than-human participatory research. In: Bastian M, Jones O, Moore N, Roe E (eds) 2017 'Participatory research in more-than-human worlds'. Routledge, Oxford

Batavia C, Nelson MP (2017) For goodness sake! What is intrinsic value and why should we care? Biol Cons 209:366-376

Becker G (1974) A theory of social interactions. J Polit Econ 82:1095-1117

Bergold J, Thomas S (2012) Participatory research methods: a methodological approach in motion. Histor Soc Res 2012:191-222

Braat LC (2018) Five reasons why the Science publication "Assessing nature's contributions to people" (Diaz et al. 2018) would not have been accepted in Ecosystem Services. Ecosyst Serv 30:A1-A2. https://doi.org/10.1016/j.ecoser.2018.02.002

Bryman A (2008) Qualitative data analysis. Social research methods, 3rd edn. Oxford University Press, Oxford

Buller H (2015) Animal geographies II. Prog Hum Geogr 39(3):374-384

Cafaro P (2001) Thoreau, Leopold, Carson: toward an environmental virtue ethics. Environ Ethics 22:14

Callicott JB (1992) Rolston on intrinsic value. Environ Ethics 14:129-143 
Carson R, Flores N, Meade N (2001) Contingent valuation: controversies and evidence. Environ Resour Econ 19:1730219

Chan KM, Goldstein J, Satterfield T, Hannahs N, Kikiloi K, Naidoo R, Vadeboncoeur N, Woodside U (2011) Cultural services and non-use values. In: Kareiva P (ed) Natural capital: theory and practice of mapping ecosystem services. Oxford University Press, Oxford, pp 206-228

Chan KM, Satterfield T, Goldstein J (2012) Rethinking ecosystem services to better address and navigate cultural values. Ecol Econ $74: 8-18$

Chan KM, Balvanera P, Benessaiah K, Chapman M, Díaz S, GómezBaggethun E, Gould R, Hannahs N, Jax K, Klain S, Luck GW (2016) Opinion: why protect nature? Rethinking values and the environment. Proc Natl Acad Sci 113(6):1462-1465

Chan KM, Gould RK, Pascual U (2018) Relational values: what are they, and what's the fuss about? Curr Opin Environ Sustain 35:A1-A7. https://doi.org/10.1016/j.cosust.2018.11.003

Church A, Fish R, Haines-Young R, Mourato S, Tratalos J, Stapleton L, Willis C, Coates P, Gibbons S, Leyshon C, Potschin M, Ravenscroft N, Sanchis-Guarner R, Winter M, Kenter JO (2014) UK national ecosystem assessment follow-on. Work package report 5: cultural ecosystem services and indicators. UNEP-WCMC, Cambridge

Comberti C, Thornton TF, de Echeverria VW, Patterson T (2015) Ecosystem services or services to ecosystems? Valuing cultivation and reciprocal relationships between humans and ecosystems. Glob Environ Change 34:247-262

Cooper N, Brady E, Steen H, Bryze R (2016) Aesthetic and spiritual values of ecosystems: recognising the ontological and axiological plurality of cultural ecosystem 'services'. Ecosyst Serv 21:218-229

Costanza R, de Groot R, Braat L, Kubiszewski I, Fioramonti L, Sutton P, Farber S, Grasso M (2017) Twenty years of ecosystem services: how far have we come and how far do we still need to go? Ecosyst Serv 28:1-16

De Groot R, Brander L, Van Der Ploeg S, Costanza R, Bernard F, Braat L, Christie M (2012) Global estimates of the value of ecosystems and their services in monetary units. Ecosyst Serv 1(1):50-61

Díaz S, Demissew S, Carabias J, Joly C, Lonsdale M, Ash N, Larigauderie A, Adhikari JR, Arico S, Báldi A, Bartuska A (2015) The IPBES conceptual framework-connecting nature and people. Curr Opin Environ Sustain 14:1-16

Díaz S, Pascual U, Stenseke M, Martín-López B, Watson RT, Molnár Z, Hill R, Chan KMA, Baste IA, Brauman KA, Polasky S, Church A, Lonsdale M, Larigauderie A, Leadley PW, Van Oudenhoven APE, van der Plaat F, Schröter M, Lavorel S, Aumeeruddy-Thomas Y, Bukvareva E, Davies K, Demissew S, Erpul G, Failler P, Guerra CA, Hewitt CL, Keune H, Lindley S, Shirayama Y (2018) Assessing nature's contributions to people. Science 359:270-272

Dryzek J (1990) Green reason: communicative ethics for the biosphere. Environ Ethics 12:195-210

Eckersley R (2011) Representing nature. In: Alonso S, Keane J, Merkel W (eds) The future of representative democracy. Cambridge University Press, Cambridge, pp 236-257

Everard M, Reed MS, Kenter JO (2016) The ripple effect: Institutionalising pro-environmental values to shift societal norms and behaviours. Ecosyst Serv 21:230-240. https://doi.org/10.1016/j. ecoser.2016.08.001

Faith D (2018) Avoiding paradigm drifts in IPBES: reconciling "nature's contributions to people", biodiversity, and ecosystem services. Ecol Soc 23:art40

Fish R, Church A, Winter M (2016) Conceptualising cultural ecosystem services: a novel framework for research and critical engagement. Ecosyst Serv 21:208-217

Funtowicz SO, Ravetz JR (1994) The worth of a songbird: ecological economics as a post-normal science. Ecol Econ 10(3):197-207
Gould R, Pai M, Chan K, Muraca B (2019) How one indigenous worldview informs relational values and social values. Sustain Sci (under revision)

Gunton RM, van Asperen EN, Basden A, Bookless D, Araya Y, Hanson DR, Goddard MA, Otieno G, Jones GO (2017) Beyond ecosystem services: valuing the invaluable. Trends Ecol Evol 32(4):249-257

Habermas J (1990) The philosophical discourse of modernity; moral consciousness and communicative action (trans. C. Lenhart \& S. W. Nicholson). MIT Press, Cambridge

Henry M (1963) L'essence de la manifestation. Presses Universitaires de France, Paris

Himes A, Muraca B (2018) Science direct relational values: the key to pluralistic valuation of ecosystem services. Curr Opin Environ Sustain 35:1-7

Hodgetts T, Lorimer J (2015) Methodologies for animals' geographies: cultures, communication and genomics. Cult Geogr 22(2):285-295

Ingold T (2000) The perception of the environment. Psychology Press, London

Ingold T (2011) Being alive: essays on movement, knowledge and description. Routledge, New York

IPBES (2016) Preliminary guide regarding diverse conceptualisation of multiple values of nature and its benefits, including biodiversity and ecosystem functions and services. UNEP, Nairobi

IPBES (2019) Summary for policymakers of the global assessment report on biodiversity and ecosystem services of the Intergovernmental Science-Policy Platform on Biodiversity and Ecosystem Services. https://www.ipbes.net/sites/default/files/downloads/ spm_unedited_advance_for_posting_htn.pdf

Irvine KN, O'Brien L, Ravenscroft N, Cooper N, Everard M, Fazey I, Reed MS, Kenter JO (2016) Ecosystem services and the idea of shared values. Ecosyst Serv 21:184-193. https://doi.org/10.1016/j. ecoser.2016.07.001

Ives CD, Kendal D (2014) The role of social values in the management of ecological systems. J Environ Manage 144:67-72

Jax K, Barton DN, Chan KM, de Groot R, Doyle U, Eser U, Görg C, Gómez-Baggethun E, Griewald Y, Haber W, Haines-Young R (2013) Ecosystem services and ethics. Ecol Econ 93:260-268

Justus J, Colyvan M, Regan H, Maguire L (2009) Buying into conservation: intrinsic versus instrumental value. Trends Ecol Evol 24(4):187-191

Kenter JO (2016) Editorial: shared, plural and cultural values. Ecosyst Serv 21:175-183. https://doi.org/10.1016/j.ecoser.2016.10.010

Kenter JO (2018) IPBES: don't throw out the baby whilst keeping the bathwater; Put people's values central, not nature's contributions. Ecosyst Serv 33:40-43. https://doi.org/10.1016/j.ecose r.2018.08.002

Kenter JO, Raymond C, Van Riper CJ, Azzopardi E, Brear MR, Calcagni F, Christie I, Christie M, Fordham A, Gould RK, Ives CD, Hejnowicz AP, Gunton R, Horcea-Milcu A, Kendal D, Kronenberg J, Massenberg JR, O'Connor S, Ravenscroft N, Rawluk A, Raymond IJ, Rodríguez-Morales J, Thankappan S (2019) Loving the mess: Navigating diversity and conflict in social values for sustainability. Sustain Sci (under revision)

Kenter JO, Hyde T, Christie M, Fazey I (2011) The importance of deliberation in valuing ecosystem services in developing countries-evidence from the Solomon Islands. Glob Environ Change 21:505-521. https://doi.org/10.1016/j.gloenvcha.2011.01.001

Kenter JO, Reed MS, Irvine KN, O’Brien L, Brady E, Bryce R, Christie M, Church A, Cooper N, Davies A, Hockley N, Fazey I, Jobstvogt N, Molloy C, Orchard-Webb J, Ravenscroft N, Ryan M, Watson V (2014) UK National Ecosystem Assessment follow-on phase. Work Package Report 6: shared, plural and cultural values of ecosystems. UNEP-WCMC, Cambridge. https://doi.org/10.13140/ rg.2.1.1275.6565 
Kenter JO, O’Brien L, Hockley N, Ravenscroft N, Fazey I, Irvine KN, Reed MS, Christie M, Brady E, Bryce R, Church A, Cooper N, Davies A, Evely A, Everard M, Fish R, Fisher JA, Jobstvogt N, Molloy C, Orchard-Webb J, Ranger S, Ryan M, Watson V, Williams S (2015) What are shared and social values of ecosystems? Ecol Econ 111:86-99. https://doi.org/10.1016/j.ecole con.2015.01.006

Kenter JO, Jobstvogt N, Watson V, Irvine KN, Christie M, Bryce $R$ (2016a) The impact of information, value-deliberation and group-based decision-making on values for ecosystem services: integrating deliberative monetary valuation and story telling. Ecosyst Serv 21:270-290. https://doi.org/10.1016/j.ecose r.2016.06.006

Kenter JO, Reed MS, Irvine KN, O'Brien E, Bryce R, Christie M, Cooper N, Hockley N, Fazey I, Orchard-Webb J, Ravenscroft N, Raymond CM, Tett P, Watson V (2016b) Shared values and deliberative valuation: future directions. Ecosyst Serv 21:358-371. https://doi.org/10.1016/j.ecoser.2016.10.006

Kenter JO, Reed MS, Fazey I (2016c) The deliberative value formation model. Ecosyst Serv 21:194-207. https://doi.org/10.1016/j. ecoser.2016.09.015

Klain SC, Olmsted P, Chan KM, Satterfield T (2017) Relational values resonate broadly and differently than intrinsic or instrumental values, or the New Ecological Paradigm. PLoS One 12(8):e0183962

Landis JR, Koch GG (1977) The measurement of observer agreement for categorical data. Biometrics 1977:159-174

Leopold A (1949) A sand county almanac and sketches here and there. Oxford University Press, New York

Maguire LA, Justus J (2008) Why intrinsic value is a poor basis for conservation decisions. Bioscience 58:910-911

Martinez-Alier J, Munda G, O’Neill J (1998) Weak comparability of values as a foundation for ecological economics. Ecol Econ 26:277-286

Martinez-Alier J, Munda G, O’Neill J (1999) Commensurability and compensability in ecological economies. In: O'Connor M, Spash $\mathrm{C}$ (eds) Valuation and the environment: theory, method and practice. Edward Elgar Publishing, Cheltenham

McCauley DJ (2006) Selling out on nature. Nature 443(7107):27

Meffe GK, Carroll CR (1994) Principles of conservation biology. Sinauer Associates Inc, Sunderland

Meinard Y, Dereniowska M, Gharbi J-S (2016) The ethical stakes in monetary valuation methods for conservation purposes. Biol Cons 199:67-74

Muraca B (2011) The map of moral significance: a new axiological matrix for environmental ethics. Environ Value 20:375-396

Naess A (1988) Ecology, community and lifestyle. Outline of an ecosophy. Cambridge University Press, Cambridge

O'Neill J (1992) The varieties of intrinsic value. Monist 75(2):119-137

O'Neill J, Holland A, Light A (2008) Environmental values. Routledge, London

O’Neill J (2001) Representing people, representing nature, representing the world. Environ Plan C Govern Policy 19(4):483-500

Orchard-Webb J, Kenter JO, Bryce R, Church A (2016) Deliberative democratic monetary valuation to implement the ecosystem approach. Ecosyst Serv 21:308-318. https://doi.org/10.1016/j. ecoser.2016.09.005

Pascual U, Balvanera P, Díaz S et al (2017) Valuing nature's contributions to people: the IPBES approach. Curr Opin Environ Sustain 26-27:7-16. https://doi.org/10.1016/j.cosust.2016.12.006

Pellizzoni L (2003) Uncertainty and participatory democracy. Environ Values 12(2): 195-224

Piccolo JJ (2017) Intrinsic values in nature: objective good or simply half of an unhelpful dichotomy? J Nat Conserv 37:8-11

Ranger S, Kenter JO, Bryce R, Cumming G, Dapling T, Lawes E, Richardson PB (2016) Forming shared values in conservation management: an interpretive-deliberative-democratic approach to including community voices. Ecosyst Serv 21:344-357. https ://doi.org/10.1016/j.ecoser.2016.09.016

Ravenscroft N (2010) The mythologies of environmental economics. J Policy Res Tour Leisure Events 2(2):129-143

Ravenscroft N (2019) A new normative economics for the formation of shared social values. Sustain Sci. https://doi.org/10.1007/s1162 5-018-0652-4

Rawluk A, Ford R, Anderson N, Williams K (2019) Exploring multiple dimensions of values and valuing: a conceptual framework for mapping and translating values for social-ecological research and practice. Sustain Sci. https://doi.org/10.1007/s11625-018-0639-1

Raymond CM, Kenter JO (2016) Transcendental values and the valuation and management of ecosystem services. Ecosyst Serv 21:241-257. https://doi.org/10.1016/j.ecoser.2016.07.018

Raymond CM, Kenter JO, Plieninger T, Turner NJ, Alexander KA (2014) Comparing instrumental and deliberative paradigms underpinning the assessment of social values for cultural ecosystem services. Ecol Econ 107:145-156. https://doi.org/10.1016/j. ecolecon.2014.07.033

Raymond CM, Giusti M, Barthel S (2017) An embodied perspective on the co-production of cultural ecosystem services: toward embodied ecosystems. J Environ Plan Manag 1:1-22

Rodela R (2012) Advancing the deliberative turn in natural resource management: an analysis of discourses on the use of local resources. J Environ Manage 96:26-34

Rolston H III (1982) Are values in nature subjective or objective? Environ Ethics 4:125-151

Sagoff M (1998) Aggregation and deliberation in valuing environmental public goods: a look beyond contingent pricing. Ecol Econ 24(2):213-230

Scholte SSK, van Teeffelen AJA, Verburg PH (2015) Integrating socio-cultural perspectives into ecosystem service valuation: a review of concepts and methods. Ecol Econ 114:67-78. https:// doi.org/10.1016/j.ecolecon.2015.03.007

Schröter M, Zanden EH, Oudenhoven AP, Remme RP, Serna-Chavez HM, Groot RS, Opdam P (2014) Ecosystem services as a contested concept: a synthesis of critique and counter-arguments. Conserv Lett 7(6):514-523

Silvertown J (2015) Have ecosystem services been oversold? Trends Ecol Evol 30(11):641-648

Stålhammar S, Pedersen E (2017) Recreational cultural ecosystem services: how do people describe the value? Ecosyst Serv 26:1-9

Stålhammar S, Thorén H (2019) Three perspectives on relational values of nature. Sustain Sci. https://doi.org/10.1007/s11625-019-00718 $-4$

Stone C (1972) Should trees have standing. South Calif Law Rev 45:450-501

Svoboda T (2011) Why there is no evidence for the intrinsic value of non-humans. Ethics Environ 16(2):25-36

TEEB (2010) The economics of ecosystems and biodiversity: the ecological and economic foundations. Earthscan, London

Temper L, Martinez-Alier J (2013) The god of the mountain and Godavarman: net present value, indigenous territorial rights and sacredness in a bauxite mining conflict in India. Ecol Econ 96:79-87

Tewdwr-Jones M, Allmendinger P (1998) Deconstructing communicative rationality: a critique of Habermasian collaborative planning. Environ Plan A 30(11):1975-1989

UK NEA (2014) UK national ecosystem assessment follow-on phase: synthesis report. UNEP-WCMC, Cambridge

UK NEA (2011) The UK national ecosystem assessment: synthesis of key findings. UNEP WCMC, Cambridge

United Nations Office of the High Commissioner for Human Rights (2016) Report of the Special Rapporteur on the rights of indigenous peoples (A/71/229). http://ap.ohchr.org/documents/dpage _e.aspx?si=A/71/229 
Warren KJ (1990) The power and the promise of ecological feminism. Environ Ethics 12(2):125-146

Wilber K (2001) No boundary. Shambhala Publications, Boston

Zografos C, Howarth RB (2010) Deliberative ecological economics for sustainability governance. Sustainability 2(11):3399-3417
Publisher's Note Springer Nature remains neutral with regard to jurisdictional claims in published maps and institutional affiliations. 